\title{
How Changes in Exports, Remittances and Fdi and Their Impacts on Reserves After Currency Floating. (Research on: Turkey)
}

\author{
Doaa Wafik Nada, Assem Tharwat
}

\begin{abstract}
Cash depreciation is a monetary association pursued by using positive international locations for collection of motives, for instance, conducting a particular swapping scale objective or restoring competitiveness in the international marketplace. The reasons behind receiving coins cheapening range from country to nation and the results also are tormented by a few internal variables recognized with the economic system and legislative issues of the nation or perhaps outside elements. On this paper, we can research how cash downgrading of the Egyptian pound need to reason a optimistic final effects at the Egyptian absolute out of doors stores quick gold. Likewise, we will draw on the Turkish involvement in debasement and after that deliver suggestions at the maximum talented technique to build the wonderful impact of depreciation on the Egyptian whole outside stores using time association information from 1985 to 2016 have been given from a unique immediately relapse version for Turkey. Next to breaking down the results, we observed that fares are the most extensive aspect in helping out of doors shops and are profoundly profiting with the useful resource of the choice of coasting the cash, taking into account that each kingdom has various conditions therefore this examination will beconsidering producing arrangements becoming Egypt.
\end{abstract}

Keywords: Devaluation, monetary policy, Egyptian pound, foreign reserves, multiple linear regression models, Turkish experience

\section{INTRODUCTION}

\subsection{Devaluation}

The state's cash associated approach makes a decision if there's adecline within the estimation of its coins and that is related with the aid of the crucial financial institution when maintaining the arrival of allowed to marketplace powers (unfastened market activity) to determine the value of its community cash in opposition to others within the remote exchange market.it's miles valid that the antagonism of debasement brings about growth which can be brought approximately through better import costs, lower profitability and talent of close by firms due to lower aggressiveness subsequent to lessening imports, expanding out of doors cash obligation, horrifying international speculators off after devaluation of their assets and in a while it's far hard to keep them and repair their confidence in particular if there are out of doors people. this means the country have to be especially cautious when settling on coins debasement choices in light of the reality that in order to diminish the affects of enlargement, the groups ought now not pass the enlargement in import costs to consumers and reduce their gain irrespective of whether or not in the interim and joined by using extra high-priced fees and increment reimbursement.anyhow, there are as yet numerous nations who accept that they may get a few benefits from the manner of cash depreciation, mainly for boosting the interest in their items within the outer markets which can make an improvement the province's situation all in all. The fundamental cause for positive countries devaluating their cash is basically to develop their fares inside the worldwide market where the charges of items turn out to be more affordable than previously, making sending out countries, as an example, China and India are hustling to downgrade the cash of the purported race to the lowest.some other point is to pick up parity of installments with the aid of contracting the change deficiencies so that it will be an outcome ofincreasing fares and afterward imports will grow to be increasingly high-priced making them drop. similarly, degrading would help reduce the estimation of sovereign responsibility gave that there is no huge range of remote bonds. At long final, the expansion in the fares and overall demandwill push towards better monetary development quotes. what is greater, cash debasement is trailed by way of many developing nations as a route for settling their economy and is reinforced by using the global financial Fund, which in its turn protected extraordinary conditions, for instance, improved prices, financing charges and lower neighborhood use and credit score. settling on the selection of the right conversion standard is one of the most massive economic additives to construct improvement and preserve up stability;however there may be no particular framework this is perfect for all international locations. Is it vital to take note of that the effect of the swapping scale is not just now not pretty the same as one state to some other, however it's miles evendifferent a number of the unique segments internal a comparable state and the reasons for that iselasticity of interest and capital intensity.furthermore, there are a few advantageous determinants of the selection to degrade the money and this could in all likelihood arise while positive elements are met. these include whether or not the enterprise cycle situation is stale, the hobby is adaptable inside the brief which might accelerate the 
improvement of the present file. moreover, if the aggressiveness of residential gadgets is feeble, this will carry sends out as hobby increments after depreciation if the nation's change and creation structure and the extent of receptiveness to widely wide-spread change are significant.

intending onward, the deterioration of the cash empowers the compulsory utilization of the residential merchandise and the reason is on the grounds that each one the imported matters presently grew to become out to be an increasing number of steeply-priced and possibly won't be accessible any further. This idea likewise underpins neighborhood the tour industry because voyaging overseas might be exorbitant just as targeting residential items being traded to worldwide markets. Provincial monetary alliances just like the ecu Union, the North American free change agreement (NAFTA) and the affiliation of Southeast Asian countries (ASEAN) have made markets that help part sends out, pushing them to settle their swapping scale or even actuate an ordinary coins as within the euro accumulating (Husted et al., 2013). during the time spent money skimming, the normal inquiry can be what is the maximum giant self sufficient thing that has the best tremendous impact on the size of outdoor shops in Turkey? inside the wake of investigating the Turkish version and experiencing its estimation and relapse exam, we count on that fares can be the maximum enormous independent component because the Turkish economy depends at the auxiliary faculty which

spotlights on ventures then introduction thenexport ultimately at the travel enterprise, whose earning are viewed as a first-rate component of the fare income .In enlargement, considering each Egypt and Turkey have confronted comparative monetary problems just as them having comparative focuses, for instance, floor territory and populace, on this manner we be given that Egypt can definitely take the manner of Turkish financial change.

\subsection{Egypt earlier than Devaluation}

In January 2003, the vital financial institution of Egypt declared the gliding of the pound where it moved from preserving up a set conversion scale bendy while the greenback kept on ascending to about $14 \%$ with extended out of doors stores from 15 billion greenbacks to 35 billion greenbacks. After the global financial emergency that came about between September 2008 and March 2009, outdoor interest for merchandise and assets of far flung protections diminished from 32 billion pounds to a thousand million kilos. The significant financial institution mediates until balancing out the conversion widespread, which tumbled to LE 5.62 Egyptian.

The dependability of the conversion scale on the grounds that 2005 is the aftereffect of the nonstop obstruction by using the crucial financial institution. however the expansion in improvement, the gathering of faraway shops, excessive swelling and the sustenance emergency, the swapping scale stayed settled. Financing prices saved on ascending to draw in faraway inflows and money associated policiestargeted diminishing enlargement, increasing saves and dealing with the exchange price.The years following the unrest inside the Egyptian pound are partitioned into three number one instances: the first eratook area somewhere inside the range of 2011 and 2013, the second someplace inside the range of 2013 and 2016 at the same time as the 1/3 time began in 2016 and proceeds until today.all through the principle time, out of doors trade through Suez Canal diminished by using an all out shortfall of 0.9 billion bucks however alternatively, outside exchange improvedbecause of direct remote challenge, fares, settlements and outside advances with an all out increment of 15.four billion greenbacks, while the outside exchange stores descended from 20 to five. 15 billion dollars in may additionally 2012, the estimation of the pound fallen and the bootleg market rose. one of the number one reasons this happened become the inaccessibility of capital, ventures and the trade of advantages like Orascom institution for industry and creation. As indicated via the IMF website online, this took place in light of the fact that Egypt is getting a rate out of a huge share of possibility because of the capital development which even outperformed Brazil, China and Chile. besides, the principal bank attempted to force confinements, as an instance, greatest rate card withdrawals, money swaps and innovative governments went to expanding foreignborrowings.the second one time which started out from 2013 and completed in 2016 isknown because the emergency of the dollar where the cost accelerated on the underground market and the earning of the majority of its resources dwindled no matter the high extent of faraway investments. The estimation of the dollar kept on growing notwithstanding while the parity of installments was in surplus and this was for the maximum part a result of the exit of outdoor coins as premiums, enthusiasm on advances and outer obligation carrier.right here, the valuable financial institution depended on present second and medium-term borrowings with the intention to cowl remote shops. This situation lead to help borrowings till the installment of increase portions and solicitations for the import of wheat, gasoline and mechanical facts sources and the essential point turned into to forestall in addition growth. At long ultimate, the 0.33 time which proceeds till these days started whilst the critical financial institution declared its desire to coast the Egyptian pound and that took place on the third of November of that year. With this preference got here a few desires, for example, information the emergency of remote preserve deficiency and the disposal of the dark marketplace.This precipitated soundness in swelling charges somewhere within the variety of 10 and 11 percentage and dwindled spending shortfall too asfurther increment in fares and advancement of ventures. It changed into visible via the vital financial institution information that tailing 12 months of the buoyancy choice, the internet faraway sources achieved a top of LE 82.three billion after it turned into terrible (Hussein, 2016).

\subsection{Following the Devaluation in Turkey}

Inside the 365 days 2000, the political and monetary troubles that Turkey had experienced amassed, in particular the breakdown of the cash related market, absolutely the dependence on far flung hypothesis and the giant spending shortfall. To take care of its issues, Turkey tried all 
endeavors to assure borrowings from the IMF in that same yearbycommitting itself to executing each one of the states of the reserve making use of the monetary simple change programwhich integrated the disposal of appropriations on gadgets, coasting the coins and receiving extreme somberness strategies. At that aspect on the twenty second of February 2001, the Turkish lira changed into glided.

Following the coasting preference in Turkey, the dollar ascended through 69.Eight $\%$ in the direction of the lira without delay from the number one day whilst the loan fee executed $3000 \%$ and the treasured financial organization out of place 5 billion bucks of its far flung holds due to the increase renowned for the lira. Be that as it is able to, the monetary unrest expanded in the initial eight months of 2001, swelling rose to 70 percent and half of of Turkey's banks went bankrupt.Lira coasting brought about the Turkish economic system depending extra onattracting outdoor financial professionals and to make this feasible, numerous administration controls had been decreased or even killed. Turkey's outside obtaining from Western banks increased and the country's far flung obligation came to $\$ 112$ billion in March 2002. All through this period, turkey targeting advancing privatization, licenses, task, transportation, agribusiness, animals, power, mining, interchanges and the adventure enterprise. Additionally, Turkey gave high attention torestructuring its cash associated framework and this result in the method of fare development, empowering technology and mechanical improvement and growing its open spend on logical studies applications.On the 0.33 of October 2004, Turkey selected to erase six zeros from its cash and issue the brand new Turkish lira which have become then renamed the Turkish lira all over again in 2008. Turkey's monetary system ascended with the resource of five.Four\% in 2001, 9.Five\% in 2004, eight.Four\% on 2005, 6.8\% on 2006 and four.7\% in 2007.Following that, the signs of the extraordinary financial fiasco began to appear in Turkey wherein the development fee dropped and gather $0.7 \%$ in 2008 and there was agrowth lower through 4.Eight\% in 2009. Be that as it is able to, this wasregained lower back to $9.2 \%$ in 2010 and 8 .Eight $\%$ in 2011 when Turkey became the second number one monetary improvement on the arena after China (Akat and Yazgan, 2012).

\section{LITERATURE EVALUATION}

\section{1 change rates in research}

The relationship amongst a ways flung exchange assets along the outside conversion scale began out to pull in specialists for the motive that Sixties and it had emerge as a vital piece of concentrates during the following forty years.To start with, Agarwal (1971) acquainted that an equalization of faraway trade helps required a difficult and rapid alternate framework whileGirton and Roper (1977)made the specified modificationon the trade price prompting modifications madeon remote exchange fundswhichwas not unusual to be because of overabundance deliver or hobby for close by cash in far off markets.

In an exploration directed via Frenkel in 1978 discovered, the growth in far off alternate stores changed into pushed by using safety towards money related emergencies and in his
1983 exam, he discussedthe preoccupation of the waste framework to coasting alternate rates which turned into regularly taking place to decrease the out of doors alternate shops and this forestall became drawn depending on the breakdown of the Bretton woods tool.Moreover, Friedman (1986)investigated every the equalization and unevenness inside the diploma of some distance off change stores and he proven that those were because of the scale of the important economic institution's change of outside markets.In 1995, Weymarkdecidedthat below the drifting conversion scale framework, the outside trade save will trade and therefore there might be an increment inside the free marketplace interest of the nearby currency.In the maximum essential decade of thenew millennium,it wasnoticed that therewas a awful associationamong some distance flung exchange property and exchange charge unpredictability (Xu, 2001).After further investigations identified with the dread of trade percentagevariationsonemergingnations, Rajan (2002) expressed that that had provoked them to possess massive assets of outdoor change save whiledeveloping worldwide places were said to revel in the unwell consequences of insecure swapping scale as an outcome of the variance of the a long way flung trade saves in their treasured Banks (Reinhart, 2002).Furthermore,Marion andAizenman(2002)proved that after conversion scale vacillations increment, remote exchange store preserving decreaseand in 2006,Smyth and Narayanstated that there has been a solid and hopeful dating a number of the realexchange price and some distance off exchange saves but simply ultimately.Following that modified into Gonzalea and Cady(2007)'sconclusion that increasing the sufficiency of some distance off change stores could bolster decrease conversion preferred instability whilePrebheeshandMalathy(2007)found the interrelationship among transient gatherings of outdoor alternate and capital streams in which they have located that the stores effectson the capital streams which emerge as earlier than clarified byYi in 2007, in which he expressed thatthe degree of reliance on imports is one of the most good sized determinants of out of doors exchange saves. Within the identical yr,Choi andBaek(2007)referred to the backwards relationship amongst change price adaptability and outside alternate save stability at that component following thatPaladino andCifarelli(2008)provedthebig and useful very last effects of the loan cost and the swapping scale inside the americaa. Which has an impact at the growth of its crucial bank's interest for remote exchange saves.

Furthermore,AyhanandKasman(2008)confirmed that there might be no connection between trade prices and some distance off change saves in the end.In an exam led thru AizenmanandRierain 2008, the focus became onthe industrialized countrieswhere theyhave located the effect of warm cash to be more noteworthy and to have extra importance on conversion fashionable change than on outside alternate reserves.Moving on, considers established the circuitous effect of outdoor exchange on the depth of 
approach through the usage of demonstrating that increasing out of doors alternate shops lessens the depth of approach (Reinhart and Reinhart, 2008) and that in a version marketplace economic gadget there's a connection between complete scale arrangement and outside trade saves choices (Liao, 2008).

An end changed into drawn at the decrease conversion trendy maintaining it bolsters the collection of outside alternate saves (Chiu, 2008)and what is greater, RebeloandVegh(2008) confirmed that severa countries have surrendered the constant swapping scale in spite of overabundance far off change saves in their focal banks.It's miles likewise regular that there are informative elements within the complete scale economy that are stimulated to amplify the benefits of out of doors change saves, as an instance, change receptiveness, GDP, deliver out instability and mortgage charge spread (Chee and Wan, 2009). Just as of late, it changed into regarded in Ito andChim(2010's) inspect that at the off threat that the far flung change shop improved above $24 \%$ of the GDP, at that factor it'd keep away from swapping scale alternate and bring about balance. Chinn, Aizenmanand Ito (2010)in addition dissected far off change segments and found that its stores surpass its impact on the conversion elegant, yet in addition on the warranty of the kind of swapping scale framework and it is common that there may be a protracted haul associationamong outside trade saves and the exchange rate (Hoshikawa, 2012).

Nicholas Wright 2013, used theMacroeconomic balance (MB) and the natural real exchange rate (NATREX) ways to deal with examine the 2 extents of the equalization certifiable swapping scale, this exam controls for agency cycle impacts and the commitment supportability. The disclosures recommend that therewere more than one between instances of transformation scale misalignment for every u . S . A ., which incorporates Jamaica, overthe 19902010 examination period. The swapping scale misalignment course of motion changed into visible to be stationarywhich implies that there may be a protracted-run amicability advise and a steady exchange forconversion scale misalignment.In regard of Euroization of monetary tool in Kosovo it turned into observed that this motion made large scale - cash associated dauntlessness to the quantity swelling and in reality worth exchange. Anyways, just like microeconomic edges, the choppy exchange of Euro because the authentic coins of Kosovo fail to offer microeconomic top conditions, (FlamurBunjaku, 2015).

An examination uses the Generalized method of Moments (GMM) to assess financial development condition to take a gander at the association among exchange scale schedules and yield improvement in Nigeria in particular intervals from 1970 to 2014 . But with past revelations, our very own exam solidly recommends that swapping scale schedules factor of fact depend in regards to veritable coins associated execution in Nigeria because the results discover that deregulated transformation scale normal pressure economic development in Nigeria as in competition to the entire time allotment and settled alternate scale schedule. (Kenneth O. Obi et.Al. 2016)

In 2018 Ephraim Matanda, suggests the impact of dollarization on improvement and development of rising economies with unequivocal connection with Zimbabwe's association in the duration, 2009-2018. The investigation consider researches the theoretical and observational proof drawn from worldwide locations of the world that dollarized for numerous budgetary reasons. The examination used an illuminating audit setup to break up the investigation information drawn from the sphere on the effect of dollarization on money associated development and improvement opportunities of dollarized growing economies. It turned into located that dollarization changed into essential in reducing high swelling and joblessness charges to commendable measurements, prolonged absolute free marketplace movement, the (GDP), and dreams for everyday solaces of the nationals of creating countries. The exam deduced that dollarization contributed generally to the development and headway of maximum developing economies of the sector.

\section{2 evaluating Egypt and Turkey in advance than Devaluation}

As is commonly said, all streets result in Rome and right here as:

\begin{tabular}{|c|c|c|}
\hline $\begin{array}{c}\text { Years } \\
\text { before } \\
\text { Floating } \\
\end{array}$ & $\begin{array}{c}\text { Egyptian Total } \\
\text { Reserves minus Gold } \\
\text { (current US\$) }\end{array}$ & $\begin{array}{c}\text { Turkish Total } \\
\text { Reserves minus Gold } \\
\text { (current US\$) }\end{array}$ \\
\hline 16 & $12,925,785,866$ & $1,055,929,262$ \\
\hline 15 & $13,242,410,924$ & $1,411,594,877$ \\
\hline 14 & $13,588,732,090$ & $1,775,836,939$ \\
\hline 13 & $14,273,202,432$ & $2,344,492,888$ \\
\hline 12 & $20,609,055,556$ & $4,780,460,641$ \\
\hline 11 & $24,461,556,812$ & $6,049,535,118$ \\
\hline 10 & $30,187,706,024$ & $5,144,174,312$ \\
\hline 9 & $32,216,142,299$ & $6,159,412,667$ \\
\hline 8 & $32,252,965,329$ & $6,271,512,909$ \\
\hline 7 & $33,611,731,752$ & $7,169,312,962$ \\
\hline 6 & $14,915,683,532$ & $12,441,845,319$ \\
\hline 5 & $11,627,543,645$ & $16,435,819,484$ \\
\hline 4 & $13,608,098,010$ & $18,658,335,762$ \\
\hline 3 & $11,995,216,166$ & $19,488,809,981$ \\
\hline 2 & $13,282,026,843$ & $23,345,860,898$ \\
\hline 1 & $20,858,153,236$ & $22,488,441,169$ \\
\hline
\end{tabular}

Table 1: Egyptian and Turkish reserves before Floating.

The below figure shows the total reserves in the two countries 16 years before the floating occurred:

Published By:

Blue Eyes Intelligence Engineering \& Sciences Publication

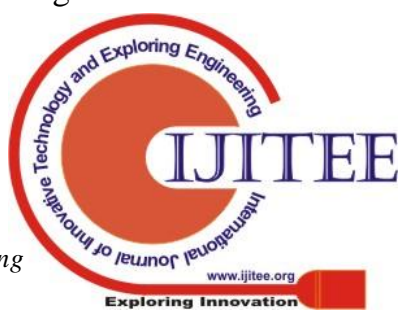




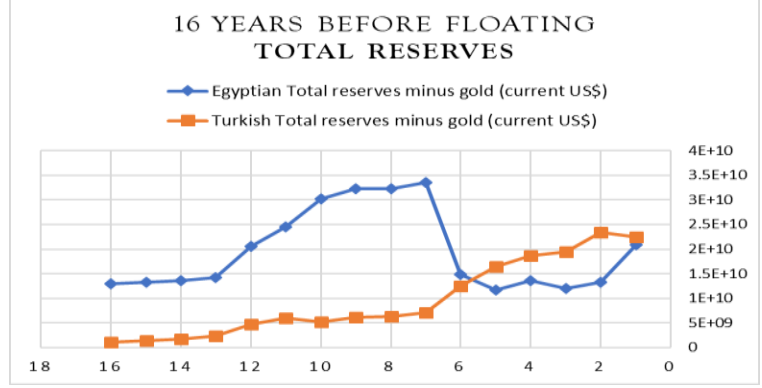

Fig 1: Comparing Total Reserves between Egypt and Turkey 16 years before Floating

\subsection{Exports of Goods and Services}

Fares are the principle wellspring of hard money and remote stores. Every nation represents considerable authority in numerous businesses that are especially gainful for them since they have an upper hand while they lean toward toimport the remainder of their needs which could be less costlycompared to their creation. This is a significant thought with the goal that the expense of imports does not surpass the fare income.

In the table underneath, the Egyptian fares of products and enterprises before coasting were contrasted with those of Turkey's and it was seen that Turkey was further developed than Egypt now.

\begin{tabular}{|c|c|c|}
\hline $\begin{array}{c}\text { Years } \\
\text { before } \\
\text { Floating }\end{array}$ & $\begin{array}{c}\text { Egyptian Exports of } \\
\text { Goods and Services } \\
\text { (current US\$) }\end{array}$ & $\begin{array}{c}\text { Turkish Exports of } \\
\text { Goods and Services } \\
\text { (current US } \$ \text { ) }\end{array}$ \\
\hline 16 & $17,065,868,263$ & $10,663,948,826$ \\
\hline 15 & $16,090,888,013$ & $10,081,244,162$ \\
\hline 14 & $18,074,562,536$ & $13,582,253,229$ \\
\hline 13 & $22,257,964,940$ & $16,947,657,046$ \\
\hline 12 & $27,213,830,088$ & $17,360,346,518$ \\
\hline 11 & $32,191,268,336$ & $20,138,041,278$ \\
\hline 10 & $39,469,535,055$ & $20,765,547,619$ \\
\hline 9 & $53,800,000,000$ & $22,805,811,594$ \\
\hline 8 & $47,163,995,068$ & $24,636,054,545$ \\
\hline 7 & $46,731,006,458$ & $27,918,206,081$ \\
\hline 6 & $48,539,511,507$ & $33,713,478,166$ \\
\hline 5 & $45,808,657,936$ & $39,094,658,477$ \\
\hline 4 & $49,111,159,371$ & $46,664,617,512$ \\
\hline 3 & $43,520,045,901$ & $56,721,035,673$ \\
\hline 2 & $43,862,395,687$ & $47,537,824,737$ \\
\hline 1 & $34,442,761,209$ & $53,091,138,836$ \\
\hline
\end{tabular}

Table 2: Egyptian and Turkish Exports of Goods and Services before Floating

The graph below compares the exports of goods and services in both Egypt and Turkey 16 years before floating happened:
16 YEARS BEFORE FLOATING EXPORTS

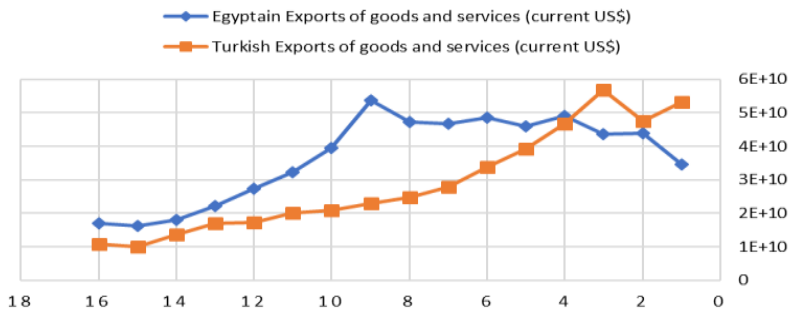

Fig 2: Comparing the Egyptian and Turkish Exports of Goods and Services before Floating

\subsection{Personal Remittances Received}

Laborers' settlements are an optional wellspring of hard money which the nation can profit by it. It is significant that the human capital is very much dealt with so it meets all requirements to the degree that makes its residents needed in different nations. Be that as it may, it ought to likewise be sharp that those natives go about as a surplus to the necessities of the neighborhood work showcase so that there is no cerebrum channel and after that the bootleg market must be killed. Underneath, we look at the biggest offer unquestionably for Egypt as the graph appears (Todaro and Smith, 2012).

\begin{tabular}{|c|c|c|}
\hline $\begin{array}{c}\text { Years } \\
\text { before } \\
\text { Floating }\end{array}$ & $\begin{array}{c}\text { Egyptian Personal } \\
\text { Remittances, Received } \\
\text { (current US\$) }\end{array}$ & $\begin{array}{c}\text { Turkish Personal } \\
\text { Remittances, } \\
\text { Received (current } \\
\text { US\$) }\end{array}$ \\
\hline 16 & $2,911,400,000$ & $1,714,000,000$ \\
\hline 15 & $2,893,100,000$ & $1,634,000,000$ \\
\hline 14 & $2,960,900,000$ & $2,021,000,000$ \\
\hline 13 & $3,340,700,000$ & $1,776,000,000$ \\
\hline 12 & $5,017,300,000$ & $3,063,000,000$ \\
\hline 11 & $5,329,500,000$ & $3,246,000,000$ \\
\hline 10 & $7,655,800,000$ & $2,819,000,000$ \\
\hline 9 & $8,694,000,000$ & $3,008,000,000$ \\
\hline 8 & $7,149,600,000$ & $2,919,000,000$ \\
\hline 7 & $12,453,100,000$ & $2,627,000,000$ \\
\hline 6 & $14,324,300,000$ & $3,327,000,000$ \\
\hline 5 & $19,236,400,000$ & $3,542,000,000$ \\
\hline 4 & $17,833,100,000$ & $4,197,000,000$ \\
\hline 3 & $19,570,400,000$ & $5,356,000,000$ \\
\hline 2 & $18,325,400,000$ & $4,533,000,000$ \\
\hline 1 & $16,590,000,000$ & $4,560,000,000$ \\
\hline
\end{tabular}

Table 3: Egyptian and Turkish Remittances Received before Floating 
How Changes In Exports, Remittances And Fdi And Their Impacts On Reserves After Currency Floating. (research on: turkey)

The below graph shows the difference between the Egyptian and Turkish Personal Remittances:

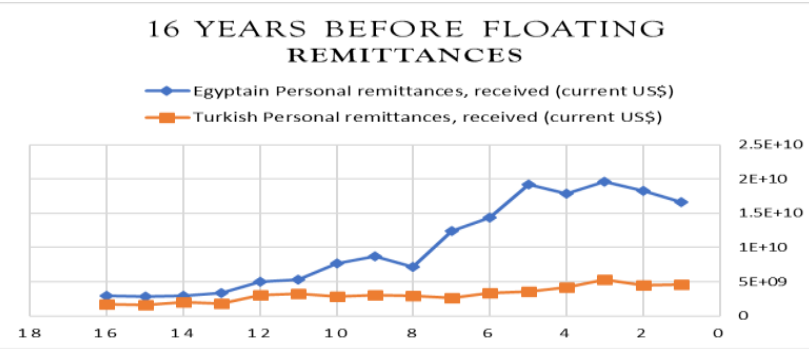

Fig 3: Comparing Egyptian and Turkish Remittances Received before Floating

\subsection{Foreign Direct Investment and Net Inflows}

For countries to advantage from FDI/MNCs, there are sure conditions to be met. at first the agreements of these offices must be non-monopolistic because of the reality those sorts of agreements diminish restriction inside the home market and limit of the pay must be reinvested. these enterprises should depend intensely on nearby product inside the mediator and capital merchandise in inclination to transferring them from the nation of the parent association. in addition, it ought to depend on neighborhood efforts and offer instruction bundles for them for you to upgrade their capacities. some other basic factor is that the expense concessions provided to these associations should be compelled in cost and time.underneath is a difference among Egypt and Turkey in the outside Direct Investments and web Inflows sooner than drifting occurred:

\begin{tabular}{|c|c|c|}
\hline $\begin{array}{c}\text { Years } \\
\text { before } \\
\text { Floating }\end{array}$ & $\begin{array}{c}\text { Egyptian Foreign } \\
\text { Direct Investment and } \\
\text { Net Inflows (current } \\
\text { US\$) }\end{array}$ & $\begin{array}{c}\text { Turkish Foreign } \\
\text { Direct Investment and } \\
\text { Net Inflows (current } \\
\text { US\$) }\end{array}$ \\
\hline 16 & $509,900,000$ & $99,000,000$ \\
\hline 15 & $646,900,000$ & $125,000,000$ \\
\hline 14 & $237,400,000$ & $115,000,000$ \\
\hline 13 & $1,253,300,000$ & $354,000,000$ \\
\hline 12 & $5,375,600,000$ & $663,000,000$ \\
\hline 11 & $10,042,800,000$ & $684,000,000$ \\
\hline 10 & $11,578,100,000$ & $810,000,000$ \\
\hline 9 & $9,494,600,000$ & $844,000,000$ \\
\hline 8 & $6,711,600,000$ & $636,000,000$ \\
\hline 7 & $6,385,600,000$ & $608,000,000$ \\
\hline 6 & $(482,700,000)$ & $885,000,000$ \\
\hline
\end{tabular}

\begin{tabular}{|l|l|l|}
\hline 5 & $2,797,700,000$ & $722,000,000$ \\
\hline 4 & $4,192,200,000$ & $805,000,000$ \\
\hline 3 & $4,783,200,000$ & $940,000,000$ \\
\hline 2 & $6,884,800,000$ & $783,000,000$ \\
\hline 1 & $8,106,800,000$ & $982,000,000$ \\
\hline
\end{tabular}

Table 4: Egyptian and Turkish Foreign Direct Investment and Net Inflows before Floating 16 YEARS BEFORE FLOATING FDI

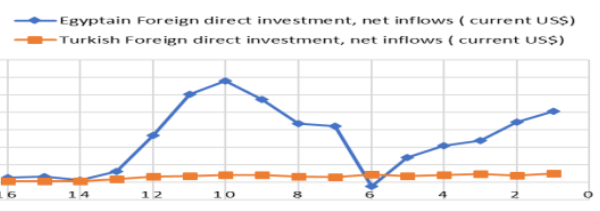

Fig 4: Comparing Egyptian and Turkish Foreign Direct Investment and Net Inflows before Floating

\section{DATA DESCRIPTION AND REGRESSION ANALYSIS RESULTS}

3.1 Turkey Before and After Devaluation Model and Time Series Data

here, we measure the impact of devaluation thru figuring out the effect size for the maximum vital 3 unbiased variables " dollar sources "on overseas exchange reserves in Turkey before and then after floating change price in the periods between 1985 to2000 and2001 to 2016 respectively, as proven underneath:

1-Dummy Variable "Devaluation"

2-Exports of goods and services (current US\$)

3-Personal remittances, received (current US\$)

4-Foreign direct investment, net inflows (current US\$)

\section{The General Form of the model:}

Total reserves minus gold (current US\$)

$=\mathbf{C 0}+\mathbf{C 1}$ Dummy Variable

+C2 Exports of goods and services (current US\$)

+ C3 Personal remittances, received (current US\$)

+ C4 Foreign direct investment, net inflows (current US\$)

+ residualerror

\subsection{Data Collection}

Table (5) measures the impact of degrading through deciding the effect estimate for the most significant autonomous factors " dollar assets "on remote exchange holds in Turkey before the coasting conversion scale in the period from 1985 to 2000 and then in the wake of gliding swapping scale from 2001 to2016.

\begin{tabular}{|c|l|c|c|c|c|}
\hline Year & $\begin{array}{c}\text { Dummy } \\
\text { Variable }\end{array}$ & $\begin{array}{c}\text { Total reserves } \\
\text { minus Gold } \\
\text { (current US\$) }\end{array}$ & $\begin{array}{c}\text { Exports of Goods } \\
\text { and Services } \\
\text { (current US\$) }\end{array}$ & $\begin{array}{c}\text { Personal } \\
\text { Remittances, } \\
\text { Received (current } \\
\text { US\$) }\end{array}$ & $\begin{array}{c}\text { Foreign Direct } \\
\text { Investment and } \\
\text { Net Inflows ( } \\
\text { current US\$) }\end{array}$ \\
\hline 1985 & 0 & $1,055,929,262$ & $10,663,948,826$ & $1,714,000,000$ & $99,000,000$ \\
\hline 1986 & 0 & $1,411,594,877$ & $10,081,244,162$ & $1,634,000,000$ & $125,000,000$ \\
\hline
\end{tabular}




\begin{tabular}{|l|l|c|c|c|c|}
\hline 1987 & 0 & $1,775,836,939$ & $13,582,253,229$ & $2,021,000,000$ & $115,000,000$ \\
\hline 1988 & 0 & $2,344,492,888$ & $16,947,657,046$ & $1,776,000,000$ & $354,000,000$ \\
\hline 1989 & 0 & $4,780,460,641$ & $17,360,346,518$ & $3,063,000,000$ & $663,000,000$ \\
\hline 1990 & 0 & $6,049,535,118$ & $20,138,041,278$ & $3,246,000,000$ & $684,000,000$ \\
\hline 1991 & 0 & $5,144,174,312$ & $20,765,547,619$ & $2,819,000,000$ & $810,000,000$ \\
\hline 1992 & 0 & $6,159,412,667$ & $22,805,811,594$ & $3,008,000,000$ & $844,000,000$ \\
\hline 1993 & 0 & $6,271,512,909$ & $24,636,054,545$ & $2,919,000,000$ & $636,000,000$ \\
\hline 1994 & 0 & $7,169,312,962$ & $27,918,206,081$ & $2,627,000,000$ & $608,000,000$ \\
\hline 1995 & 0 & $12,441,845,319$ & $33,713,478,166$ & $3,327,000,000$ & $885,000,000$ \\
\hline 1996 & 0 & $16,435,819,484$ & $39,094,658,477$ & $3,542,000,000$ & $722,000,000$ \\
\hline 1997 & 0 & $18,658,335,762$ & $46,664,617,512$ & $4,197,000,000$ & $805,000,000$ \\
\hline 1998 & 0 & $19,488,809,981$ & $56,721,035,673$ & $5,356,000,000$ & $940,000,000$ \\
\hline 1999 & 0 & $23,345,860,898$ & $47,537,824,737$ & $4,533,000,000$ & $783,000,000$ \\
\hline 2000 & 0 & $22,488,441,169$ & $53,091,138,836$ & $4,560,000,000$ & $982,000,000$ \\
\hline 2001 & 1 & $18,879,204,309$ & $53,222,799,445$ & $2,786,000,000$ & $3,352,000,000$ \\
\hline 2002 & 1 & $27,068,604,095$ & $58,321,175,690$ & $1,936,000,000$ & $1,082,000,000$ \\
\hline 2003 & 1 & $33,990,987,298$ & $69,359,206,476$ & $729,000,000$ & $1,702,000,000$ \\
\hline 2004 & 1 & $35,669,143,453$ & $92,090,930,901$ & $804,000,000$ & $2,785,000,000$ \\
\hline 2005 & 1 & $50,579,001,445$ & $105,387,000,000$ & $1,368,000,000$ & $10,031,000,000$ \\
\hline 2006 & 1 & $60,891,881,640$ & $119,616,000,000$ & $1,833,000,000$ & $20,185,000,000$ \\
\hline 2007 & 1 & $73,383,889,916$ & $143,400,000,000$ & $2,096,000,000$ & $22,047,000,000$ \\
\hline 2008 & 1 & $70,428,064,106$ & $174,469,000,000$ & $2,439,000,000$ & $19,851,000,000$ \\
\hline 2009 & 1 & $70,873,658,129$ & $145,519,000,000$ & $1,834,000,000$ & $8,585,000,000$ \\
\hline 2010 & 1 & $80,712,976,523$ & $157,840,000,000$ & $1,819,000,000$ & $9,099,000,000$ \\
\hline 2011 & 1 & $78,322,384,557$ & $185,345,000,000$ & $1,883,000,000$ & $16,182,000,000$ \\
\hline 2012 & 1 & $99,942,631,728$ & $206,848,000,000$ & $1,881,000,000$ & $13,744,000,000$ \\
\hline 2013 & 1 & $110,927,000,000$ & $211,719,000,000$ & $1,901,000,000$ & $13,563,000,000$ \\
\hline 2014 & 1 & $106,906,000,000$ & $221,999,000,000$ & $1,739,000,000$ & $13,119,000,000$ \\
\hline 2015 & 1 & $92,920,826,755$ & $200,727,000,000$ & $1,395,000,000$ & $18,002,000,000$ \\
\hline 2016 & 1 & $92,054,531,730$ & $189,715,000,000$ & $1,186,000,000$ & $13,343,000,000$ \\
\hline
\end{tabular}

Table 5: Total Reserves minus Gold, Exports of Goods and Services, Personal Remittances, Received and Foreign Direct Investment and Net Inflows of Turkey

Turkish Model Estimation and its Regression Analysis

After conducting the first regression, EViews' results are demonstrated in the Figure below:

\begin{tabular}{|c|c|c|c|c|}
\hline Variable & Coefficient & Std. Error & $\mathrm{t}$-Statistic & Prob. \\
\hline C & $-3.91 E+09$ & $3.33 \mathrm{E}+09$ & -1.176153 & 0.2498 \\
\hline DUMMY_VARIABLE & $7.25 \mathrm{E}+08$ & 3.57E+09 & 0.202854 & 0.8408 \\
\hline EXPORTS_OF_GOODS_AND_SE... & 0.503113 & 0.027456 & 18.32461 & 0.0000 \\
\hline PERSONAL_REMITTANCES_RE & -0.278363 & 1.013270 & -0.274717 & 0.7856 \\
\hline FOREIGN_DIRECT_INVESTMEN & -0.068821 & 0.232744 & -0.295695 & 0.7697 \\
\hline R-squared & 0.986003 & \multicolumn{2}{|c|}{ Mean dependent var } & $3.93 \mathrm{E}+10$ \\
\hline Adjusted R-squared & 0.983930 & \multicolumn{2}{|c|}{ S.D. dependent var } & $3.66 \mathrm{E}+10$ \\
\hline S.E. of regression & $4.64 \mathrm{E}+09$ & \multicolumn{2}{|c|}{ Akaike info criterion } & 47.49713 \\
\hline Sum squared resid & $5.82 \mathrm{E}+20$ & \multicolumn{2}{|c|}{ Schwarz criterion } & 47.72616 \\
\hline Log likelihood & -754.9542 & \multirow{2}{*}{\multicolumn{2}{|c|}{$\begin{array}{l}\text { Hannan-Quinn criter. } \\
\text { Durbin-Watson stat }\end{array}$}} & 47.57305 \\
\hline F-statistic & 475.5131 & & & 2.518455 \\
\hline Prob(F-statistic) & 0.000000 & & & \\
\hline
\end{tabular}

Fig 5: EView'sFirst Regression Model Results

The information appeared in Figure (5) demonstrates that there is a multicollinearity issue since multicollinearity has a solid straight connection between a few or the majority of the logical factors which makes Y ridiculous in light of the fact that the estimation of R-squared is extremely high yet couple of huge t-insights. Besides, we likewise discovered an autocorrelation issue which alludes to the connection of mistake term in the present time frame with the blunder term in the past period.This relationship prompts standard mistake predisposition or a wrong measurable huge test just as off-base certainty interims in light of the fact that Durbin Watson worth would fall in a hesitant zone.

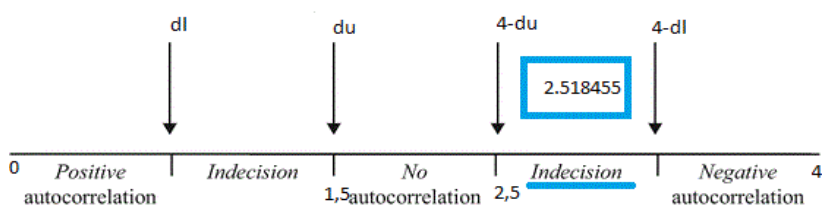

Fig 6: First Regression Presentation

Here, we decided to use the transformation of variables to overcome the multicollinearity problem so we divided all variables on foreign direct investment.EViews' results after second regressions are shown below:

Published By:

Blue Eyes Intelligence Engineering

\& Sciences Publication 


\begin{tabular}{|c|c|c|c|c|}
\hline Variable & Coefficient & Std. Error & t-Statistic & Prob. \\
\hline C & -0.158542 & 1.267224 & -0.125110 & 0.9013 \\
\hline DUMMY_VARIABLE/FOREIGN_DIRECT_IN... & $-8.24 \mathrm{E}+09$ & $4.22 \mathrm{E}+09$ & -1.950317 & 0.0612 \\
\hline EXPORTS_OF_GOODS_AND_SER/FOREI... & 0.660667 & 0.075664 & 8.731551 & 0.0000 \\
\hline PERSONAL_REMITTANCES_RE/FOREIG... & -3.319105 & 0.476995 & -6.958373 & 0.0000 \\
\hline R-squared & 0.795754 & \multicolumn{2}{|c|}{ Mean dependent var } & 11.40061 \\
\hline Adjusted R-squared & 0.773871 & \multicolumn{2}{|c|}{ S.D. dependent var } & 7.251735 \\
\hline S.E. of regression & 3.448420 & \multicolumn{2}{|c|}{ Akaike info criterion } & 5.430178 \\
\hline Sum squared resid & 332.9649 & \multicolumn{2}{|c|}{ Schwarz criterion } & 5.613395 \\
\hline Log likelihood & -82.88285 & \multicolumn{2}{|c|}{ Hannan-Quinn criter. } & 5.490909 \\
\hline F-statistic & 36.36326 & \multirow{2}{*}{\multicolumn{2}{|c|}{ Durbin-Watson stat }} & 1.566749 \\
\hline Prob(F-statistic) & 0.000000 & & & \\
\hline
\end{tabular}

Fig 7: EView's First Regression Model Results

In the above results we found out the following:

Detecting multicollinearity:

R-Squared $=0.795754$ high value $\}$, and all independent variable statistically significant, so according to this rule there is no problem.

Detecting autocorrelation:

Durbin-Watson stat $=1.566749$, so $4-d u>d \_c a l>d u$ in no autocorrelation area where we accept $\mathrm{H} 0$ and reject $\mathrm{H} 1$, So according to this rule there is no problem

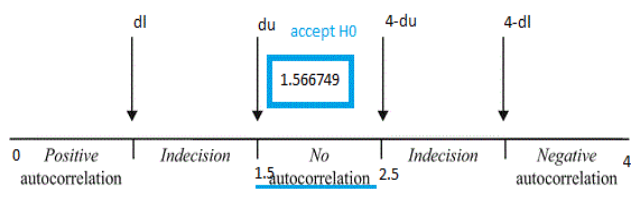

Fig 8: Second Regression Presentation

\section{Regression Analysis:}

the subsequent assumptions had been used in the take a look at:

- monetary Assumption:

in step with economic priori, we would assume a positive relationship between general reserves and exports, remittances and FDI whilst anybody of independent variables modifications. The dependent variable will alternate within the identical direction even as keeping all different matters steady.

- Economic-test:

The estimated results show that:

- $\mathrm{C} 1=7.25 \mathrm{E}+08$, Parameter of dummy variable is a positive valuetherefore the floating of the Turkish currency has positive impact on foreign reserves in Turkey.

The below figure shows that Turkey's total foreign reserves increased significantly after the devaluation of the Turkish lira in 2001:

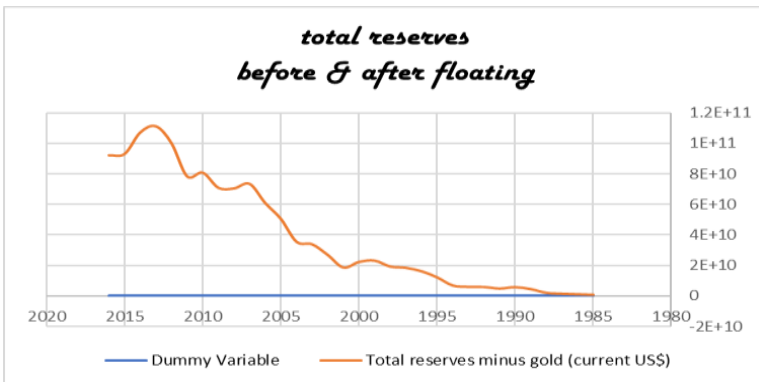

Fig 9: Total Reserve Before and After Floating
Besides, $C 2=0.503113$ [the slant of fares of products and services], is a positive worth so it is as per monetary priori, infers that when fares changes by 1 unit, stores will change by 0.503113 unit a similar way, so it is monetarily noteworthy. Figure 10 likewise demonstrates that Turkish fares expanded fundamentally after the cheapening of the money in 2001, joined by a critical increment altogether outside stores.

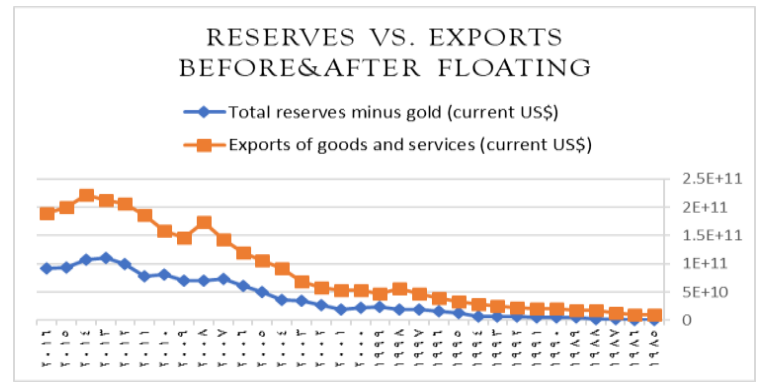

\section{Fig 10: Comparing Reserves versus Exports Before and After Floating}

it's far vital to note that $\mathrm{C} 3=-0.278363$ [the slope of personal remittances], is a negative price so it isn't according with monetary priori, implies that while remittances changes via 1 unit, reserves will alternate by means of 0.278363 unit inside the opposite route, so it is economically insignificant. searching at figure eleven, we will additionally notice that people' remittances did not exchange substantially after the devaluation of the lira and have been by no means a firstrate cause for the boom in the total foreign reserves after 2001.

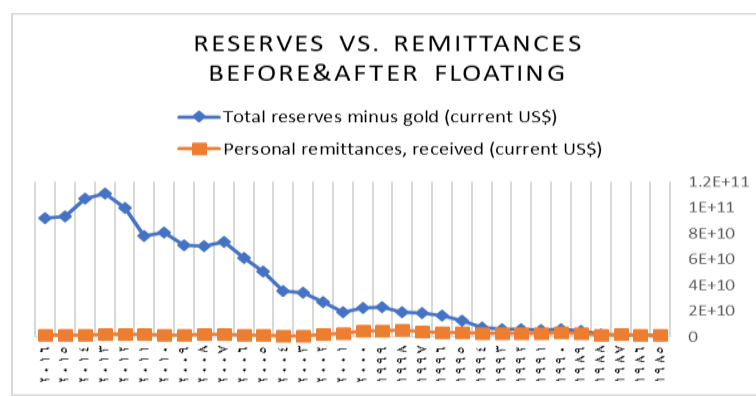

Fig 11: Comparing Reserves versus Remittances Before and After Floating

In addition, $\mathrm{C} 4=-0.068821$ [the slope of $\mathrm{FDI}$ ], is a negative value so it is not accordance with economic priori and this implies that when FDI net inflow changes by oneunit, total reserves will change by 0.068821 unit in the opposite direction, so it is economically insignificant.

Figure 12 shows that the volume of foreign direct investment after the devaluation of the lira was fluctuating and had a somewhat weak effect on the increase of foreign reserves in Turkey after 2001:

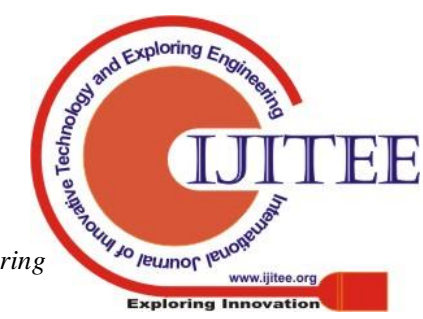




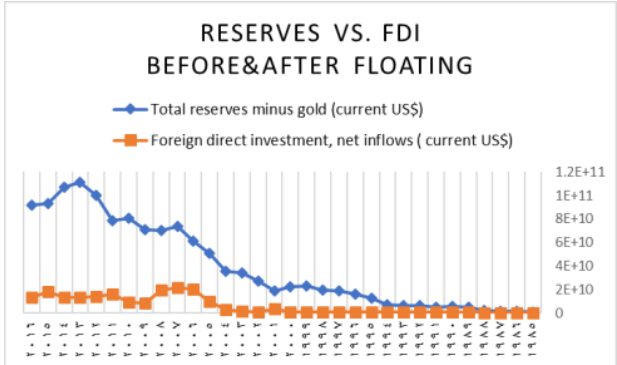

Fig 12: Reserves versus FDI Before and After Floating

After conducting the T-statistic-test, we found out the below results:

- $\quad \mathrm{t}-\mathrm{C} 1=0.202854$, that less than 2 , which mean lies in confident level(CL) area, so we accept $\mathrm{H} 0$ and reject $\mathrm{H} 1$, this implies that $\mathrm{C} 1$ is statistically insignificant.

$\{\mathrm{H} 0: \mathrm{C} 1=0 \rightarrow$ has insignificant impact

$\mathrm{H} 1: \mathrm{C} 1 /=0 \rightarrow$ has a significant impact $\}$

Prob-C1 $=0.8408>0.1 \rightarrow$ Insignificant.

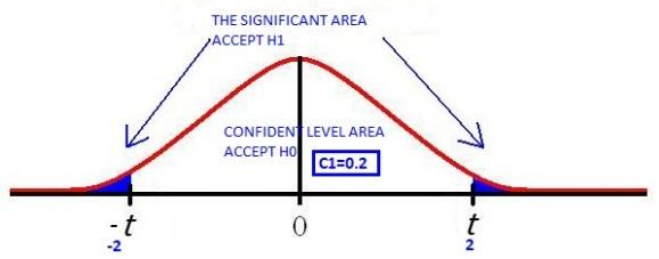

Fig 13: t-C1 Graph

Here, we note that $\mathrm{t}-\mathrm{C} 2=18.32461$, that is greater than 2 , indicates that it lies in the significant level, so we reject $\mathrm{HO}$ and accept $\mathrm{H} 1$, this implies that $\mathrm{C} 2$ is statistically significant and its value different from zero

$\{\mathrm{H} 0: \mathrm{C} 2=0 \rightarrow$ has insignificant impact

$\mathrm{H} 1: \mathrm{C} 2 /=0 \rightarrow$ has a significant impact $\}$

Prob-C2 $=0.0000<0.1 \rightarrow$ Significant.

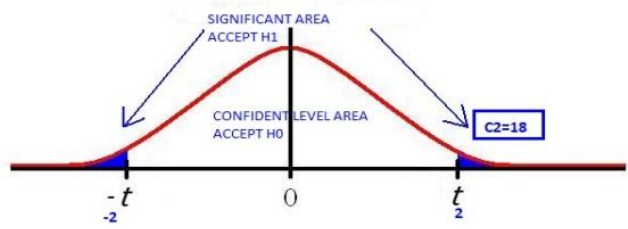

Fig 14: t-C2 Graph

According to Figure 14, t-C3=-0.274717, that is less than 2 , which means it lies in the confident level, so we accept $\mathrm{H} 0$ and reject $\mathrm{H} 1$, this implies that $\mathrm{C} 3$ is statistically insignificant

$\{\mathrm{H} 0: \mathrm{C} 3=0 \rightarrow$ has insignificant impact

$\mathrm{H} 1: \mathrm{C} 3 /=0 \rightarrow$ has a significant impact $\}$

Prob-C3 $=0.7856>0.1 \rightarrow$ Insignificant.

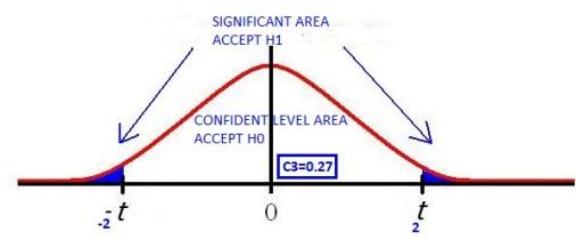

Fig 15: t-C3 Graph
Here, $\mathrm{t}-\mathrm{C} 4=-0.295695$, that is less than 2 , which mean lies in the confident level, so we accept $\mathrm{H} 0$ and reject $\mathrm{H} 1$, this implies that $\mathrm{C} 4$ is statistically insignificant $\{\mathrm{H} 0: \mathrm{C} 4=0 \rightarrow$ has insignificant impact $\mathrm{H} 1: \mathrm{C} 4 /=0 \rightarrow$ has a significant impact $\}$ Prob-C4=0.7697>0.1 $\rightarrow$ Insignificant.

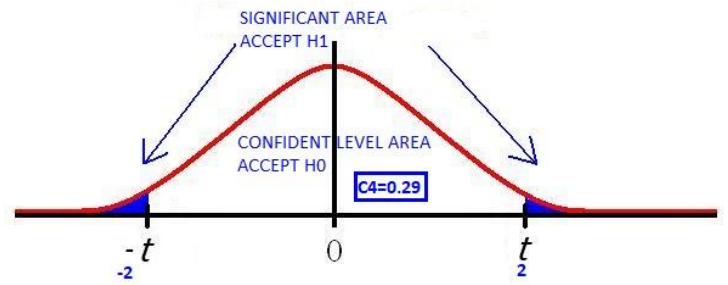

Fig 16: t-C4 Graph

R-Squared $=0.986003$ that is the coefficient of guarantee infers that \%ninety eight of the adjustment in whole stores is clarified via relapse clarified in the adjustment in fares, settlements, FDI and internet inflows. We were given a $2 \%$ from blunder term and there are special factors influencing on stores like outdoor obligations. Likewise, within the wake of directing the F-Statistic take a look at we observed that F-Statistic-take a look at $=475.5131$ with Prob$\mathrm{F}=0.0000000<$ zero. 1 , so $\mathrm{F}$ lies in alfa location, in which we renowned $\mathrm{H} 1$ and reject $\mathrm{H} 0$, this means the version is measurably large, and the model has stable healthy for the facts and excessive logical electricity.

$\{\mathrm{H} 0: \mathrm{C} 0=\mathrm{C} 1=\mathrm{C} 2=\mathrm{C} 3=\mathrm{C} 40 \rightarrow$ has insignificant impact

$\mathrm{H} 1: \mathrm{C} 0=\mathrm{C} 1=\mathrm{C} 2=\mathrm{C} 3=\mathrm{C} 4 /=0 \rightarrow$ has a significant impact $\}$

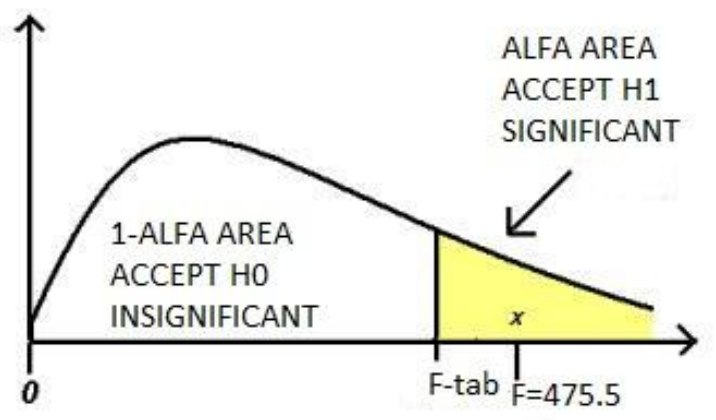

Fig 17: F-Statistic Graph

IV. DATA ANALYSIS

\section{Data Analysis and Results}

To answer to the principle studies question, after the drifting of the cash, sends out is the most excellent independent element that has the quality excellent effect on the scale of far flung saves in turkey.Exports should be depended upon as a noteworthy wellspring of outdoor shops in preference to settlements or some distance flung direct speculation. As we discover inside the table beneath, the yearly improvement fee of Turkish fares after the downgrading of the coins

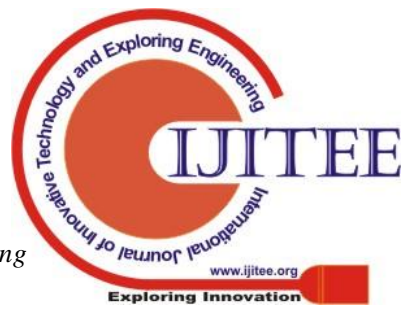


extended and in some time little by little diminished. This decay changed into the prelude to the worldwide economic emergency of 2009. Be that as it could, Turkey fast recuperated to show into the second one largest nation on earth as far as monetary development after China 2011.

\begin{tabular}{|l|c|}
\hline \multicolumn{1}{|c|}{ Year } & $\begin{array}{c}\text { Exports of Goods and Services } \\
\text { (Annual \% growth) }\end{array}$ \\
\hline 2001 & 4.590580972 \\
\hline 2002 & 7.759115498 \\
\hline 2003 & 6.744808819 \\
\hline 2004 & 11.577086460 \\
\hline 2005 & 8.116678719 \\
\hline 2006 & 6.500237460 \\
\hline 2007 & 7.279027943 \\
\hline 2008 & 3.813743763 \\
\hline 2009 & $(3.721321788)$ \\
\hline 2010 & 1.666721524 \\
\hline 2011 & 13.448408290 \\
\hline 2012 & 14.891814590 \\
\hline 2013 & 1.073539572 \\
\hline 2014 & 8.154927702 \\
\hline 2015 & 4.296725402 \\
\hline 2016 & $(1.868231576)$ \\
\hline
\end{tabular}

Table 6: Annual \% Growth for Turkish Exports and Imports between 2001 and 2016

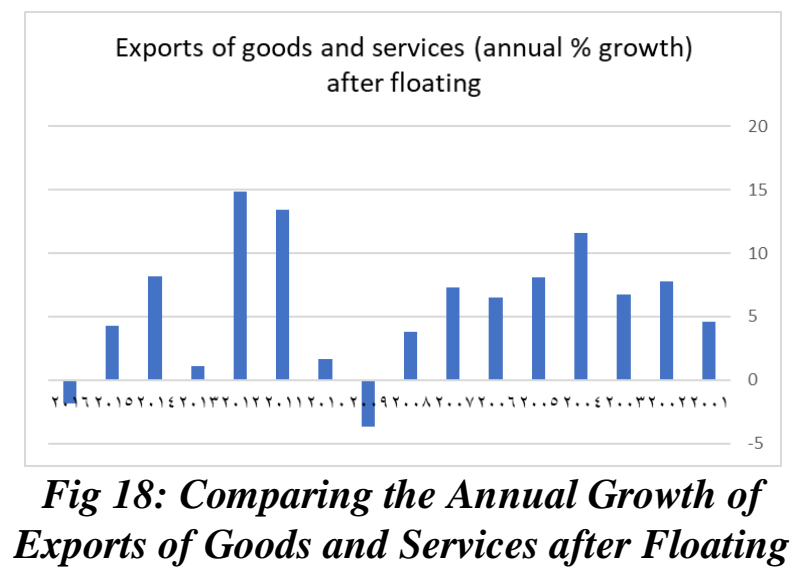

\section{AGRICULTURAL EXPORTS \& RESULTS}

While all is stated in completed, it is not critical to depend on the fare of gadgets of their essential shape in light of the reality that their fare next to putting collectively builds the extra incentive really as expands their blessings. Within the occasion that there may be some issue we need to propose to Egypt in such way, it'd ship out a rural object in which Egypt has an higher hand. However that, Egypt have to prevent the planting of gadgets which charges greater than bringing in them. As a end result, planting of each important object that is expended in big quantitiesrather than them being imported is a superior choice. As an example, planting cotton seeds in considered one of a kind terrains in no manner achieves the individual of the Egyptian cotton. On this manner, it isn't always simply essential to deliver out it in its underlying structure, but because the outstanding plans that popular manufacturers of dress pursue. Further, wheat improvement for independence on a critical level may be carried out till the import price is given thinking about the truth that it is a key item and it's far gobbled in giant quantities, in this way it should be created irrespective of whether or now not we do no longer have an top hand in its technology. What's extra, the choice of no longer to boom rice is considerable in mild of the reality that its development calls for pretty a few water and this winds up hard with the emergency of the water synchronization.As we find in table 7, the part of horticultural fares from complete product trades after degrading has dwindled, besides this has now not gone beneath a particular stage which means that that it is large if the country has an better hand, but it's far in no manner a noteworthy one.

\begin{tabular}{|c|c|}
\hline Year & $\begin{array}{c}\text { Agricultural Raw Materials Exports } \\
\text { (\% of Merchandise Exports) }\end{array}$ \\
\hline 2001 & 0.855704714 \\
\hline 2002 & 0.812235772 \\
\hline 2003 & 0.801607839 \\
\hline 2004 & 0.655002395 \\
\hline 2005 & 0.516537803 \\
\hline 2006 & 0.509746521 \\
\hline 2007 & 0.447767896 \\
\hline 2008 & 0.386846422 \\
\hline 2009 & 0.385394322 \\
\hline 2010 & 0.436565683 \\
\hline 2011 & 0.551436785 \\
\hline 2012 & 0.454288629 \\
\hline 2013 & 0.446413827 \\
\hline 2014 & 0.429422546 \\
\hline 2015 & 0.447950597 \\
\hline 2016 & 0.467361644 \\
\hline
\end{tabular}

Table 7: Percentage of Merchandise Exports of Agricultural Raw materials from 2001 to 2016 


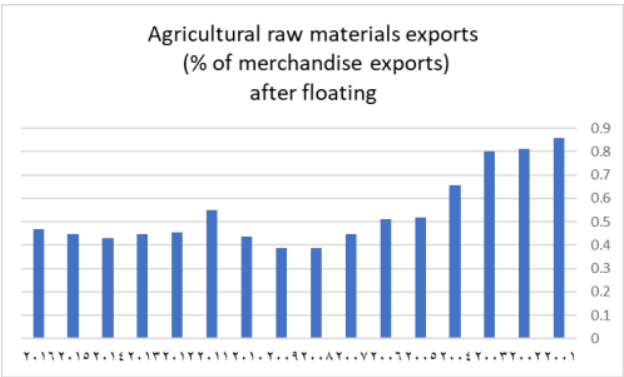

Fig 19: Agricultural Raw Materials Exports(\% of Merchandise Exports) from 2001 to 2016

\subsection{Medium and High Technology Exports}

here, it is applicable to make sure the productsare produced with excessive great because of the fact they result in very excessive profits. Our technology have to be saved up to date not handiest as a client however as a manufacturer u.s.a. and we need to stand out as sturdy competitors within the international marketplace via our refrigerators, televisions, laptops, vehicles or even airplanes. As proven in parent 20, the proportion of high technology exports of all synthetic exports turn out to be fluctuating however no longer much less than a positive extent.

\begin{tabular}{|c|c|}
\hline Year & $\begin{array}{c}\text { High-technology Exports } \\
\text { (\% of Manufactured Exports) }\end{array}$ \\
\hline 2001 & 3.871275 \\
\hline 2002 & 1.789858 \\
\hline 2003 & 1.932464 \\
\hline 2004 & 1.896814 \\
\hline 2005 & 1.474043 \\
\hline 2006 & 1.853989 \\
\hline 2007 & 1.893322 \\
\hline 2008 & 1.616625 \\
\hline 2009 & 1.738497 \\
\hline 2010 & 1.934399 \\
\hline 2011 & 1.839427 \\
\hline 2012 & 1.829741 \\
\hline 2013 & 1.878077 \\
\hline 2014 & 1.935152 \\
\hline 2015 & 2.159703 \\
\hline 2016 & 2.027279 \\
\hline
\end{tabular}

Table 8: High-technology exports (\% of manufactured exports) from 2001 to 2016

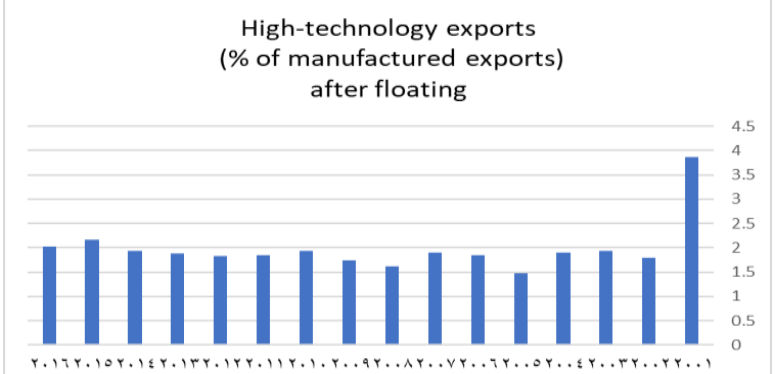

Fig 20: ComparingHigh-technology Exports (\% of Manufactured Exports) from 2001 to 2016

\section{Tourism}

The tour industry benefits are considered as a characteristic of fares. What human beings care about at the same time as visiting a rustic isto make lovable reminiscences that might make them pass again to it. Hence, it is critical to illustrate the photograph of an thrilling kingdom due to the truth that the memory of a plastic seat with umbrella earlier than a pool in a lodge can exist in a few special spot on this planet and could now not be an adequate motive inside the lower back of web site site visitors to bear in mind returning to Egypt.There are numerous nations that confine voyagers from a element in their sports for example no longer permitting a girl of the hour and man of the hour to take snap shots in the collector or Presidential royal houses. Some other version isn't always allowing womenwho shrouded their head in coastline seashores in Europe.

Proceeding onward, there are a few charming necessities related to the excursion enterprise. The term the journey enterprise for honors implies that a particular sum spent in Egypt might result in a live length for not anything out of pocket the subsequent twelve months. Additionally, festivals Tourism way that as opposed to recovering the barren region, the sand craftsmanship celebration can be held for craftsmen round the arena, in location of the Cairo shading challenge. The art work of artwork birthday party will be held for private systems and every year may be facilitated through an alternate metropolis in Egypt so craftsmen across the worldcan benefit from the journey company every year.Moreover, an entire metropolis planted with yellow bushes and roses and foundations painted with levels of a similar shading, or an entire metropolis that has as opposed to street fixtures countless a swing. Determine 21 below demonstrates the quantity of normal the tour agency receipts from the complete fares as unpredictable as it expands each some years, however there has been a certain component of confinement no a good deal less. Ultimately, it is critical to accumulate the potential to make the maximum the problems that could come up in Egypt and no longer honestly accuse the legislature, as an alternative try and remodel it into a few element satisfactory and this could assist improve unsafe casessuch as overabundance art work, rice straw and trash. 
How Changes In Exports, Remittances And Fdi And Their Impacts On Reserves After Currency Floating. (research on: turkey)

\begin{tabular}{|c|c|}
\hline Year & $\begin{array}{c}\text { International Tourism Receipts } \\
\text { (\% of Total Exports) }\end{array}$ \\
\hline 2001 & 20.14891 \\
\hline 2002 & 21.73699 \\
\hline 2003 & 18.72713 \\
\hline 2004 & 17.28497 \\
\hline 2005 & 19.52394 \\
\hline 2006 & 15.96546 \\
\hline 2007 & 14.89995 \\
\hline 2008 & 14.85605 \\
\hline 2009 & 18.09106 \\
\hline 2010 & 16.71568 \\
\hline 2011 & 16.49986 \\
\hline 2012 & 15.35946 \\
\hline 2013 & 17.23535 \\
\hline 2014 & 17.5585 \\
\hline 2015 & 17.82729 \\
\hline 2016 & 14.21111 \\
\hline
\end{tabular}

Table 9: International Tourism Receipt (\% of Total Exports) from 2001 to 2016

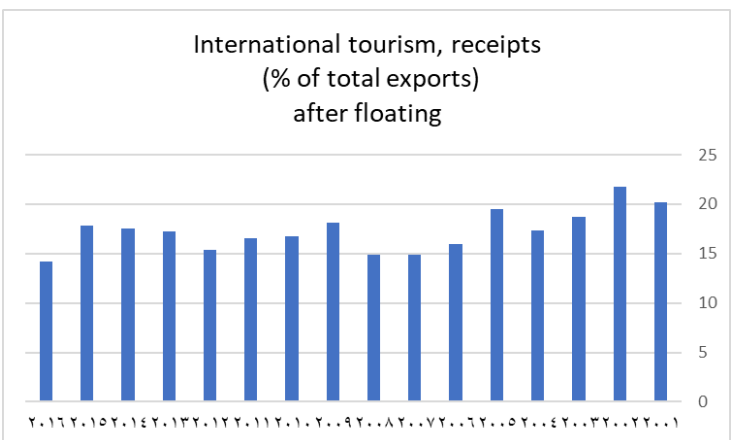

\section{Fig 21: Comparing International Tourism Receipt $(\%$ of Total Exports) from 2001 to 2016}

\section{Conclusion}

In this paper, we checked out the state of affairs at the same time as coins waft in each Turkey and Egypt. We've visible that fares have been regarded because the maximum large self maintaining element and that it has the finest high first-class impact on the dimensions of out of doors shops in Turkey. This means fares have to be depended upon as a noteworthy wellspring of outside shops in choice to settlements or far flung direct hypothesis.

Moreover, the every yr development price of the Turkish fares after the downgrading of the cash prolonged and later on step by step faded. This decay come to be the prelude to the global financial emergency of 2009.But; Turkey had proper away recuperated in 2011 to expose into the second largest u . S . A . On this planet as a ways as economic development after China. Moreover, we have were given completed up thatit is not important to rely upon the fare of objects in their essential shape in mild of the truth that their fare within the wake of assembling expands the additional simply really worth in this way prompting multiplied benefits. As a suggestion, we endorsed that Egypt ought to

deliver precise attention to sending out farming items, a location wherein Egypt has a excessive top hand. Moreover, the attention on planting the important thing item that was expended in massive amounts in location of bringing in itas properly asceasing the planting of gadgets which is probably a great deal less high priced whilst imported to the nation. On this paper, we furthermore targeted across the importance of the tour industry and its results for the nation when you consider that it's far appeared as a primary factor of fares.

At long closing, the eye at the nice is pivotal and having immoderate technologyin the $\mathrm{u} . \mathrm{S}$.'s frameworks ought to upload to the fine and create more advantage. The innovation have to be stayed up with the ultra-modern-day as a client further to a maker nation too and this would lead Egypt to have its spot among simple countries as a protracted way as headways and development. Alongside those strains, we will fortify new thoughts of advancement and superb enhancements inside the present frameworks without a doubt as growing new mindsetsto work for a superior future.

\section{REFERENCES}

1. "Egypt constitue" (2014). Retrieved from https://www.constituteproject.org/constitution/Egypt_2 014.pdf?lang=ar

2. "Exchange Rate of Egyptian Currency Historical Data" (2018). Retrieved from http://www.cbe.org.eg/en/EconomicResearch/Publicatio ns/Pages/ExternalPosition.aspx

3. "Gross Domestic Product and How It Affects You" (2019). Retrieved from https://www.thebalance.com/what-isgdp-definition-of-gross-domestic-product-3306038

4. "Income Distribution and Poverty: by country- Inequality" (2015). Retrieved from http://archive.is/UpJov

5. "International Labor Organization" (2019). Retrieved from http://www.ilo.org/

6. "Royal Canadian Mint Annual Report" (2006). Retrieved from

https://www.mint.ca/store/dyn/PDFs/RCM_AR06.pdf

7. "State and Other Areas- MAF/TIGER database as of August 2010" (2010). U.S. Census Bureau.

8. "The EPG Devaluation: A new beginning" (2017). Retrieved from https://www.pwc.com/m1/en/publications/the-egpdevaluation-a-new-beginning.html

9. "U.S. and World Population Clock" (2015). Retrieved from https://www.census.gov/popclock/

10. "Wildlife Library" (2017). National Wildlife Federation.

11. A.K. Borah and P. Goswami (2017); THE BOUNDARY ELEMENT METHOD TO THE SOLUTION OF HEAT RADIATION PROBLEMS: A NUMERICAL IMPLEMENTATION, International Journal of Engineering and Management, Vol. 4 no. 1; pp 37-44

Abderrazak DHAOUI and Fathi JOUINI (2019); R\&D INVESTMENT, GOVERNANCE AND MANAGEMENT ENTRENCHMENT, International Journal of Financial Economics and Econometrics, Vol. 6 no. 2 (2019); pp 69-90

12. Aggelopoulos S. (2017); BUSINESS RANKING BASED QUALITATIVE 
ECONOMIC PARAMETERS: APPLICATION OF A METHODOLOGICAL PATTERN ON SHEEP FARMS, International Journal of Engineering and Management, Vol. 4 no. 2; pp 83-91

13. Akat, A. \&Yazgan, M. E. (2012). Observations of Turkey's Recent Economic Performance. Atlantic Economic Journal. Vol 41(1). Pgs 1-27.

14. Arpita Mehta (2017); CUSTOMER ENGAGEMENT: A CONCEPTUAL CASE STUDY, International Journal of Engineering and Management; Vol. 4 No 1; pp 1-11

15. Atsalakis George \& Zopounidis Constantin (2018); FORECASTING TURNING POINTS IN STOCK MARKET PRICES BY APPLYING A NEURO-FUZZY MODEL, International Journal of Engineering and Management, Vol. 5 no. 2 pp 67-76

16. C. D. Lai, (2017)Hazard Rate that Asymptotes to a Constant and Applications, International Journal of Reliability and Quality Performance, Vol. 6 no. 1 pp 1-9

17. Christos Floros, Shabbar Jaffry \& Yasseen Ghulam (2019); PREDICTING RETURNS WITH FINANCIAL RATIOS: EVIDENCE FROM GREECE, International Journal of Financial Economics and Econometrics, Vol. 6 no. 1 (2019)

18. Desilver, D. (2013). Global Inequality: How the U.S. Compares. Retrieved from http://www.pewresearch.org/facttank/2013/12/19/global-inequality-how-the-u-scompares/

19. Dven Husmann and Volodymye Perederiy (2017); Forecasting Default with Aggregated Financial Ratios; JOURNAL OF MONEY BANKING and FINANCE; Vol. 1 no. 1 pp $53-68$

20. Flamur B., (2015)Exchange Rate Regimes - A periodical overview and a critical analysis of exchange rate regimes in Kosovo ISSN 2410-3918 Academic Journal of Business, Administration, Law and Social Sciences Vol 1 No 1

21. Genye, T. (2011). Currency Devaluation and Economic Growth (The Case of Ethiopia). StockholmsUniversity.

22. Hummel, J. R. (2007). Death and Taxes, Including Inflation: the Public versus Economists. Econ Journal Watch. Vol 4. No 1. Pgs 46-59.

23. Hussein, S. (2016). Three Government Myths about the Float of Egyptian Pound. Economic Justice Unit of the Egyptian Initiative for Personal Rights.

24. Husted, S. and Melvin, M. (2013). An Introduction to International Trade. Retrieved from www.pearsonhighered.com "IMF Report for Selected Countries and Subjects: Kuwait" (2015). International Monetary fund.

25. Ioannis Kekes \& Athanasios Spyridakos (2018); TOWARDS AN EVALUATION MODEL FOR EDUCATIONAL SOFTWARE ANALYZING EVALUATORS BEHAVIOR THROUGH THE MULTICRITERIA DISAGGREGATION AGGREGATION APPROACH, International Journal of Engineering and Management, Vol. 5 no. 2; pp 53-65

26. Juan, C. \& fishman, J. A. (1983). Progress in Language Planning: International Perspectives. De Gruyter. Pg 195.

27. Kenneth O., Jonathan O. , Kenneth U. (2016).The Impact of Exchange Rate Regimes on Economic Growth in Nigeria. Journal of Economics and Sustainable Development. www.iiste.org ISSN 2222-1700 (Paper) ISSN 2222-2855 (Online) Vol.7, No.12, 2016

28. Kodo Ito \& Toshio Nakagawa (2017); Optimal Operation Censoring Policy of Aircraft, International Journal of Reliability and Quality Performance, Vol. 6 no. 1 pp 19-25

29. Konstantinos Drakos., Modelling Conditional Volatility of Risk Premia on Fixed Income Instruments, International Economics and Finance Journal, Vol. 1, No. 2, p. 313.

30. Matanda E., (2018).The Costs and Benefits That Developing Countries Could Draw from Dollarization: The Zimbabwean Experience Period 2009-2018 Journal of Modern Accounting and Auditing, December 2018, Vol. 14, No. 12, 680-698 doi: 10.17265/1548-6583/2018.12.004

31. Minh Quang Dao (2018); DEMOCRACY AND URBAN POVERTY IN DEVELOPING COUNTRIES, International Journal of Financial Economics and Econometrics, Vol. 5 No. 1 , pp 1-10

32. Miniar Ben Ammar and Sami Hammami (2018); THE CAUSES OF THE DEFICIT OF HEALTH BRANCH OF SOCIAL SECURITY IN FRANCE, International Journal of Financial Economics and Econometrics, Vol. 5 No. 1, pp 7189

33. Mitsuhiro Imaizumi \& Mitsutaka Kimura (2017), Optimal Policy for a System Connected with the Radio Link, International Journal of Reliability and Quality Performance, Vol. 6 no. 1 pp 11-17

34. Mitsuhiro Kimura, Takaji Fujiwara, Tomoki Inoue \& Naomichi Hata (2017); A Software Reliability Assessment Method under Imperfect Testing Environment, International Journal of Reliability and Quality Performance, Vol. 6 no. 2 pp 55-64

35. Motasam Tatahi and Esra T.Kabaklarli (2017); The Financial and Operating Performance of Privatized Firms in France; JOURNAL OF MONEY BANKING and FINANCE; Vol. 1 no. $1 \mathrm{pp} 27-51$

36. Muhammad Hustafa and Emmanuel Anoruo (2017); Transmission Effect of Volatility Between Stock Market Returns, Economic Growth and Productivity-Wage Gap; JOURNAL OF MONEY BANKING FINANCE; Vol. 1 no. 2 pp $1-16$

37. Natalie Hegwood and M.H.Tuttle (2017); Did the Mortgage Interest Rate Fail to Respond to Federal Funds Rate Changes: Testing for a Short-Run Break, 2002-2005; JOURNAL OF MONEY BANKING and FINANCE; Vol. 1 no. 1 pp 13-26

38. Nicola Costantino \& Roberta Pellegrino (2018); REAL OPTION APPROACH FOR THE EVALUATION OF INVESTMENT PROJECTS THE CASE OF A MULTIFUEL POWER STATION, International Journal of Engineering and Management, Vol. 5 no. 2; pp 95-101

39. Nikolaos Samaras (2017)BASIS UPDATE METHODS IN THE REVISED SIMPLEX METHOD, International Journal of Engineering and Management, Vol. 4 no. 1; pp 13-18

40. Noula Armand Gilbert and Nzomo Tcheunta Joseph (2018); AGRICULTURAL CRISIS AND ECONOMIC DEVELOPMENT: The African Experience of the 1980s, International Journal of Financial Economics and Econometrics, Vol. 5 No. 1, pp 11-39

41. Olha Bodnar and Taras Bodnar (2019); UNBIASED ESTIMATOR OF THE EXPECTED QUADRATIC UTILITY PORTFOLIO, International Journal of Financial Economics and Econometrics, Vol. 6 no. 1, pp 59-68

42. Olusegun H. D. (2017); CHARACTERISTICS OF ENERGY RELEASED DURING MELTING OF ALUMINIUM AND BRASS, International Journal of Engineering and Management, Vol. 4 no. 1; pp 29-35

43. Online at https://mpra.ub.unimuenchen.de/61170/MPRA Paper No. 61170, posted 8 January 2015 05:06

44. Ran Zhang (2017); Does Systematic Risk Affect A-H Price Spread?; JOURNAL OF MONEY BANKING and FINANCE, Vol. 1 no. 1 pp 1-11

Shinji Inoue \& Shigeru Yamada (2017); Optimal Testing-Effort Expending Policies Based on a TwoDimensional Software

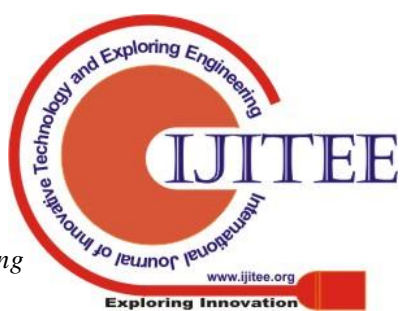


How Changes In Exports, Remittances And Fdi And Their Impacts On Reserves After Currency Floating. (research on: turkey)

Reliability Growth Model; International Journal of Reliability and Quality Performance, Vol. 6 no. 2 pp 65-77

45. Shostak, F. (2008). Commodity Prices and Inflation: What's the connection? Retrieved from https://mises.org/library/commodity-prices-andinflation-whats-connection

46. Strother-Adams, P. \&Adams,J. Q. (2014). Dealing with Diversity (2ed). Chicago, IL: Kendall/ Hunt Publishing Company.

47. Sureshkumar M. R.and V. Madhusudanan Pillai (2017); IMPACT OF WEIGHT ASSIGNED TO OBJECTIVE FUNCTIONS IN PLANNING ANNUALISED HOURS, International Journal of Engineering and Management, Vol. 4 no. $1 ;$ pp 19-27

48. Taylor, T. (2008). Principles of Economics. Houston, Texas: OpenStax.

49. Todaro, M. P. \& Smith, S. C. (2012). Economic Development. Retrieved from https://mediasrv.aua.gr/eclass/modules/document/file.p hp/AOA215/Economic\%20Development\%20\%20Todaro\%20and\%20Smith.pdf

50. Todaro, M. P. \& Smith, S.C. (2012). Foreign Finance, Investment and Aid: Controversies and Opportunities. Retrieved from www.pearsonhighered.com

51. Wahab. A. Lawal and Rihanat. I. Abdulkadir (2018); AN ANALYSIS OF GOVERNMENT SPENDING ON EDUCATIONAL SECTOR AND ITS CONTRIBUTION TO GDP IN NIGERIA, International Journal of Financial Economics and Econometrics, Vol. 5 No. 1; pp 53-70

52. Wright, N. A.(2013). Examining measures of the equilibriumReal Exchange Rate: MacroeconomicBalance and the Natural Real ExchangeRate Approaches, Bank of Jamaica

53. Xiao XIAO* \& Tadashi DOHI (2017); Exponential-Like Software Reliability Models Based on Binomial Process; International Journal of Reliability and Quality Performance, Vol. 6 no. 2 pp 79-87

54. Yihui Lan., Equilib rium Exchange Rates an d Currency Forecasts: A Big MAC Perspective, International Economics and Finance Journal, Vol. 1, No. 2, p. 291-300

55. Dan Han and Howard Qi(2019); Analyzing the Dynamics of ARM, FRM \& Hybrid Mortgage Loans, Asian Journal of Economics and Finance, Vol. 1 No. 1; pp 1-15

56. Dikaios Tserkezos (2019); Detecting ARCH Effects: Power versus Frequency of Observation. Some Monte Carlo results, Asian Journal of Economics and Finance, Vol. 1 No. 1; pp 1623

57. Yu Chun Wang, Chung Jung Lee and KuoCheng Huang (2019); Corporate Governance, Investment Opportunities and Cash Holdings for SEO Firms: A Test of the Shareholder Power Hypothesis; Asian Journal of Economics and Finance, Vol. 1 No. 1

58. pp pp 24-46. 